\section{What is already known on this topic}

Few studies have examined the link between exposure to secondhand smoke and mortality

\section{What this study adds}

Adults who had never smoked and who lived with smokers had about $15 \%$ higher mortality than never smokers living in a smoke-free household

This study strengthens the case for a causal association between secondhand smoke and mortality

as smoking and exposure to secondhand smoke outside the home were more prevalent in New Zealand in the early 1980s. This may explain the apparently stronger association between household exposure and mortality in the 1996-9 cohort compared with the 1981-4 cohort.

The results from this study add to the weight of evidence of harm caused by passive smoking and support steps to reduce exposure to other people's smoke-in the home and in other settings.
We thank Jackie Fawcett and June Atkinson for technical help with data extraction and analysis.

Contributors: SEH conceived the study, analysed the data, and drafted the manuscript. TAB conceived and led the New Zealand census-mortality study (NZCMS) from which data for this study were drawn; advised on study design, data analysis, and interpretation; and contributed to the manuscript. AW and IK advised on the design, analysis, and interpretation of the study and contributed to the manuscript. SEH and TAB will act as joint guarantors for this paper.

Funding: The NZCMS is primarily funded by the Health Research Council of New Zealand, with further funding from the Ministry of Health. Funding for SEH's salary came from the New Zealand Population Health Charitable Trust.

Competing interests: None declared.

Ethical approval: Not needed-see security statement on bmj.com

1 Sandler D, Comstock G, Helsing K, Shore D. Deaths from all causes in non-smokers who lived with smokers. Am J Public Health 1989;79:163-7.

2 Svendsen K, Kuller L, Martin M, Ockene J. Effects of passive smoking in the multiple risk factor intervention trial. Am J Epidemiol 1987;126: 783-95.

3 Humble C, Croft J, Gerber A, Casper M, Hames CG, Tyroler HA. Passive smoking and 20-year cardiovascular disease mortality among nonsmoking wives, Evans County, Georgia. Am J Public Health 1990;80:599-601.

4 Hole D, Gillis C, Chopra C, Hawthorne V. Passive smoking and cardioresHole D, Gillis C, Chopra C, Hawthorne V.Passive smoking and cardiores-
piratory health in a general population in the west of Scotland. BMJ 1989;299:423-7.

5 Blakely T, Salmond C, Woodward A. Anonymous linkage of New Zealand mortality and census data. Aust N ZJ Pub Health 2000;24:92-5. (Accepted 5 March 2004)

doi 10.1136/bmj.38070.503009.EE

\title{
Effectiveness of nicotine patches in relation to genotype in women versus men: randomised controlled trial
}

\author{
Patricia Yudkin, Marcus Munafo, Kate Hey, Sarah Roberts, Sarah Welch, Elaine Johnstone,
} Michael Murphy, Siân Griffiths, Robert Walton

The overall effectiveness of nicotine replacement therapy could be greater if the therapy were targeted at those most likely to respond. Variants of the dopamine D2 receptor (DRD2 $32806 \mathrm{C} / \mathrm{T})$ have been implicated in the initiation and maintenance of smoking, ${ }^{12}$ and these variants may also be related to response to nicotine replacement therapy. ${ }^{3}$ Additionally, mechanisms of nicotine addiction may differ in men and women. ${ }^{4}$ With this evidence in mind, we examined whether the response to nicotine replacement therapy is modified by sex and genotype.

\section{Participants, methods, and results}

A randomised controlled trial of nicotine patches in 1991-2 recruited 1686 heavy smokers ( $\geq 15$ cigarettes a day). ${ }^{5}$ The participants wore patches for 12 weeks. Abstinence from smoking was confirmed at one week by expired carbon monoxide concentration $\leq 10 \mathrm{ppm}$, and at 12, 24, and 52 weeks by salivary cotinine concentration $\leq 20 \mathrm{ng} / \mathrm{ml}$ ( $89 \%$ of cases) or by expired carbon monoxide concentration $\leq 10 \mathrm{ppm}$.

In 1999-2000, we contacted 1532 of the 1625 participants still alive; the mean time from trial to follow up was 8.3 years. In all, 752/1532 (49\%) gave a blood sample from which DRD2 32806 was successfully typed. Reported abstinence at follow up was confirmed by plasma cotinine concentration $\leq 20 \mathrm{ng} / \mathrm{ml}$. Throughout, non-respondents were assumed to be smoking.

Participants were older than non-participants (mean age at entry to trial, 43.0 years $v 41.5$ years; $\mathrm{P}=0.002)$, more likely to be female $(59 \%(445 / 752) v$ $53 \%(410 / 780) ; \mathrm{P}=0.01)$, and more likely to have quit for a year in the trial $(11 \%(82)$ v $4 \%(33), \mathrm{P}<0.0001)$; $744(99 \%)$ reported their racial background as white.

The variant $\mathrm{T}$ allele of the dopamine $\mathrm{D} 2$ receptor DRD2 32806 (CT or TT genotype) was found in $41 \%$ $(183 / 445)$ of women and $41 \%$ of men (127/307). Within each sex, there was no difference between the genotype groups in age, number of cigarettes a day, or dependency score.

We measured effectiveness of the patches by the relative odds of abstinence for active and placebo patches over five cumulative time periods: one week, 12 weeks, 24 weeks, 52 weeks, and to follow up. Treatment by genotype and sex, and their interaction, was examined in a full logistic regression model. The three way interaction by genotype by sex was significant for all time periods $(\mathrm{P}=0.009, \quad \mathrm{P}=0.03, \mathrm{P}=0.006$, $\mathrm{P}=0.006, \mathrm{P}=0.004$ respectively), and we therefore analysed the data for men and women separately.

This article was posted on bmj.com on 19 March 2004: http://bmj.com/ cgi/doi/10.1136/bmj.38050.674826.AE
Papers pp 977,988

Department of Primary Health Care, University of Oxford, Oxford OX3 7LF

Patricia Yudkin reader

continued over

BMJ 2004;328:989-90 
Cancer Research

UK General

Practice Research

Group, Departmen

of Clinical

Pharmacology,

University of

Oxford, Radcliffe

Infirmary, Oxford

OX2 $6 \mathrm{HE}$

Marcus Munafo

research fellow

Kate Hey

research officer

Sarah Roberts

research nurse

Sarah Welch

research nurse

Elaine Johnstone

research fellow

Michael Murphy

director

Siân Griffiths

scientific officer

Robert Walton

senior research fellow

Correspondence to:

P Yudkin

pat.yudkin@

dphpc.ox.ac.uk

Biochemically confirmed abstinence from smoking by sex and DRD2 32806 genotype

\begin{tabular}{|c|c|c|c|c|c|c|}
\hline \multirow[b]{2}{*}{$\begin{array}{l}\text { Period of } \\
\text { abstinence }\end{array}$} & \multirow[b]{2}{*}{ Genotype } & \multirow[b]{2}{*}{$\begin{array}{l}\text { Active patch } \\
\text { (No (\%)) }\end{array}$} & \multirow[b]{2}{*}{$\begin{array}{l}\text { Placebo patch } \\
\text { (No (\%)) }\end{array}$} & \multirow[b]{2}{*}{$\begin{array}{c}\text { Odds ratio (95\% confidence } \\
\text { interval) }\end{array}$} & \multicolumn{2}{|c|}{ Difference in odds ratios ( $\mathrm{P}$ value) } \\
\hline & & & & & $\begin{array}{c}\text { Before } \\
\text { adjustment }\end{array}$ & After adjustment ${ }^{*}$ \\
\hline \multicolumn{7}{|l|}{ Women } \\
\hline \multirow[t]{2}{*}{1 week } & CT or TT & $42 / 93(45)$ & $13 / 90(14)$ & $4.9(2.4$ to 10.0$)$ & 0.001 & 0.001 \\
\hline & CC & $33 / 125(26)$ & $34 / 137$ (25) & 1.1 (0.6 to 1.9$)$ & & \\
\hline \multirow[t]{2}{*}{12 weeks } & CT or TT & $21 / 93(23)$ & $6 / 90(7)$ & 4.1 (1.6 to 10.7$)$ & 0.03 & 0.02 \\
\hline & CC & $16 / 125(13)$ & 17/137 (12) & 1.0 (0.5 to 2.2$)$ & & \\
\hline \multirow[t]{2}{*}{24 weeks } & CT or TT & $17 / 93(18)$ & $5 / 90(6)$ & 3.8 (1.3 to 10.8$)$ & 0.03 & 0.02 \\
\hline & $\mathrm{CC}$ & $12 / 125(10)$ & 15/137 (11) & 0.9 (0.4 to 1.9$)$ & & \\
\hline \multirow[t]{2}{*}{52 weeks } & CT or TT & $14 / 93(15)$ & $5 / 90(6)$ & 3.0 (1.0 to 8.7 ) & 0.04 & 0.02 \\
\hline & $\mathrm{CC}$ & $10 / 125(8)$ & 15/137 (11) & 0.7 (0.3 to 1.6) & & \\
\hline \multirow[t]{2}{*}{8 years } & CT or TT & $11 / 93(12)$ & $4 / 90(4)$ & 2.9 (0.9 to 9.4$)$ & 0.02 & 0.01 \\
\hline & CC & $6 / 125(5)$ & $13 / 137$ (9) & $0.5(0.2$ to 1.3$)$ & & \\
\hline \multicolumn{7}{|l|}{ Men } \\
\hline \multirow[t]{2}{*}{1 week } & CT or TT & $27 / 67(40)$ & $19 / 60(32)$ & 1.5 (0.7 to 3.0$)$ & 0.59 & 0.58 \\
\hline & CC & $40 / 91$ (44) & $26 / 89(29)$ & 1.9 (1.0 to 3.5$)$ & & \\
\hline \multirow[t]{2}{*}{12 weeks } & CT or TT & $17 / 67(25)$ & $11 / 60(18)$ & 1.5 (0.6 to 3.6$)$ & 0.46 & 0.43 \\
\hline & CC & $21 / 91(23)$ & $10 / 89(11)$ & $2.4(1.0$ to 5.4$)$ & & \\
\hline \multirow[t]{2}{*}{24 weeks } & CT or TT & $11 / 67$ (16) & $9 / 60(15)$ & 1.1 (0.4 to 2.9$)$ & 0.09 & 0.07 \\
\hline & $\mathrm{CC}$ & 17/91 (19) & $5 / 89(6)$ & $3.9(1.4$ to 11.0$)$ & & \\
\hline \multirow[t]{2}{*}{52 weeks } & CT or TT & 9/67 (13) & 9/60 (15) & 0.9 (0.3 to 2.4$)$ & 0.07 & 0.07 \\
\hline & CC & $15 / 91(16)$ & $5 / 89(6)$ & 3.3 (1.2 to 9.6$)$ & & \\
\hline \multirow[t]{2}{*}{8 years } & CT or TT & $7 / 67(10)$ & $7 / 60(12)$ & 0.9 (0.3 to 2.7) & 0.07 & 0.06 \\
\hline & CC & $12 / 91$ (13) & $3 / 89(3)$ & $4.4(1.2$ to 16.0$)$ & & \\
\hline
\end{tabular}

Periods of abstinence are cumulative, with repeated biochemical confirmation. For details see methods.

${ }^{*}$ Adjustment for age, cigarettes per day, and dependency score before quit attempt.

In women, the effectiveness of the patches differed with genotype at all time points (table). In men, the genotype groups did not differ significantly at any time. In men with CC genotype an apparent trend in effectiveness was in an implausible direction, the patches being most effective long after therapy had stopped. In both sexes, when active and placebo groups were combined, the quit rate was not related to genotype.

\section{Comment}

In women the effectiveness of nicotine patches seems to be related to genotype. Women with the variant $\mathrm{T}$ allele of the dopamine D2 receptor DRD2 32806 showed considerable benefit from patches, whereas those with the more common CC genotype did not. The increased effectiveness reflected a tendency to a higher quit rate with the active patches and a lower quit rate with placebo patches. No significant relation between genotype and patch effectiveness was seen for men.

Modelling showed that the response bias in favour of quitters and of women could not account for our results, as the bias affected the nicotine and placebo groups equally and so cancels out in the odds ratio for patch effectiveness. The results are also not explained by an association between genotype and success at quitting, as this could account for only a marginal difference in odds ratios between genotypes and would affect men and women similarly. We therefore hypothesise that nicotine replacement therapy works through different processes and is subject to different genetic influences in men and women.

We thank Lesley Jones and Alice Fuller for computing help and John Stapleton for valuable comments and suggestions.

Contributors: RW, PY, and M Murphy wrote the protocol and obtained funding. M Munafo and PY devised and carried out the analysis. KH traced subjects and administered the study; SR and SW collected patient data and took blood samples. RW established laboratory procedures; EJ and SG carried out DNA extraction and genotyping. PY wrote the paper, with critical revision by all other authors. PY is the guarantor.

Funding: The study was supported by Cancer Research UK. The sponsors of the study had no role in the study design, data collection, data analysis, data interpretation, or writing of the report.

Competing interests: None declared.

Ethical approval: Ethical approval was obtained from the Anglia and Oxford Multicentre Research Ethics Committee, and from the 86 local research ethics committees covering the areas of residence of the patients.

Noble EP, St Jeor ST, Ritchie T, Syndulko K, St Jeor SC, Fitch RJ, et al. D2 dopamine receptor gene and cigarette smoking: a reward gene? Med Hypotheses 1994;42:257-60

2 Comings DE, Ferry L, Bradshaw-Robinson S, Burchette R, Chiu C, Muhleman $\mathrm{D}$. The dopamine D2 receptor (DRD2) gene: a genetic risk factor in smoking. Pharmacogenetics 1996;6:73-9.

3 Johnstone EC, Yudkin PL, Hey K, Roberts SJ, Welch SJ, Murphy MF, et al. Genetic variation in dopaminergic pathways and short term effectivenes of the nicotine patch. Pharmacogenetics 2004;14:83-90.

4 Perkins KA, Donny E, Caggiula AR. Sex differences in nicotine effects and self-administration: review of human and animal evidence. Nicotine Tob Res 1999;1:301-15.

5 Imperial Cancer Research Fund General Practice Research Group. Randomised trial of nicotine patches in general practice: results at one year. BMJ 1994;308:1476-7.

(Accepted 11 December 2003)

doi 10.1136/bmj.38050.674826.AF

\section{Endpiece}

\section{Your time's up}

Average time US patients are allowed to speak before being interrupted by their doctors: 18 seconds.

Boyle D. The Tyranny of Numbers: Why Counting Can't Make Us Happy. London: Flamingo, 2001

Iain Bamforth,

general practitioner, Strasbourg 